Diabetologia 9, $251-254(1973)$

by Springer-Verlag 1973

\title{
Human Pancreatic Islet Tumor Cells Maintained in Vitro
}

\author{
C.C. Yip and B.P. Schimmer \\ Banting and Best Department of Medical Research, University of Toronto, Toronto, Ontario, Canada
}

Received: December 12, 1972, accepted: April 2, 1973

\begin{abstract}
Summany. Tumor cells from two human insulinomas were maintained in culture for more than 6 months. The cultured cells synthesized and secreted proinsulin and insulin; and responded to cyclic AMP ( $1 \mathrm{mM}$ ) and tolbutamide $(1 \mathrm{mM})$ stimulation with increased insulin re lease. In culture, these cells did not respond to stimulation
\end{abstract}

by high concentrations of glucose $(300 \mathrm{mg} \%)$ or by glucagon $(10 \mu \mathrm{g} / \mathrm{ml})$.

Key words: Human insulinoma, culture of dissociated tumor $\beta$-cells, insulin release in culture, stimulation of insulin release by cyclic-AMP and tolbutamide.

\section{Introduction}

Studies in vitro on the differentiation, growth and regeneration of pancreatic $\beta$-cells make use of shortterm organ cultures of embryonic, fetal, or adult pancreatic islets $\left[\begin{array}{ll}1-5 & 5\end{array}\right]$ or short-term monolayer cultures of neonatal pancreas [6]. Cultured tumor cells from functional islet adenomas offer an alternative system for such studies with the possibility of establishing a permanent functional islet cell line. In 1935, Murray and Bradley [7] studied the in vitro growth characteristics of explants from two human islet-cell adenomas for 5-6 weeks. Sando et al. [8] recently reported briefly on a culture of human islet tumor $\beta$-cells which survived for over 2 months and incorporated radioactive amino acid into proinsulin and insulin. In both instances the functional response of the culture to stimuli of insulin secretion was not investigated. The experiments reported here were carried out to examine some of the functional capacities of islet tumor cells maintained in culture. The cultured cells synthesized and secreted insulin and proinsulin; and responded to cyclic AMP $(1 \mathrm{mM})$ and tolbutamide $(1 \mathrm{mM})$ with increased insulin release.

\section{Materials and Methods}

Cells from 2 human insulinomas were dissociated at room temperature by digestion with collagenase $(0.05 \%)$ and hyaluronidase $(0.1 \%)$ in Eagle's Minimal Essential Medium [9] at pH 7.2 with stirring for $15 \mathrm{~min}$. Large tissue fragments were removed by sedimentation at unit gravity and the dissociated cells were recovered from the supernatant by centrifugation. The cells were resuspended in $75 \mathrm{~cm}^{2}$ plastic tissue culture bottles (Falcon) containing $10 \mathrm{ml} \mathrm{Ham}$ 's nutrient F 10 medium [10] supplemented with horse serum $(15 \%)$, fetal calf serum $(2.5 \%)$, penicillin $(200 \mathrm{U} / \mathrm{ml})$ and streptomycin $(200 \mu \mathrm{g} / \mathrm{ml})$ and incubated at $37^{\circ}$ in a humidified atmosphere of air- $\mathrm{CO}_{2}(95: 5 \mathrm{v} / \mathrm{v})$. The concentration of glucose in the medium was $100 \mathrm{mg} \%$. Growth medium. was replaced in each culture at 5 -day intervals. The amount of insulin secreted into the medium by the cultured islet cells (IRI, total immunoreactive insulin) was determined by radioimmunoassay [11]. The concentration of IRI in fresh growth medium without tumor cells was negligible. Cells were maintained in culture for over 6 months.

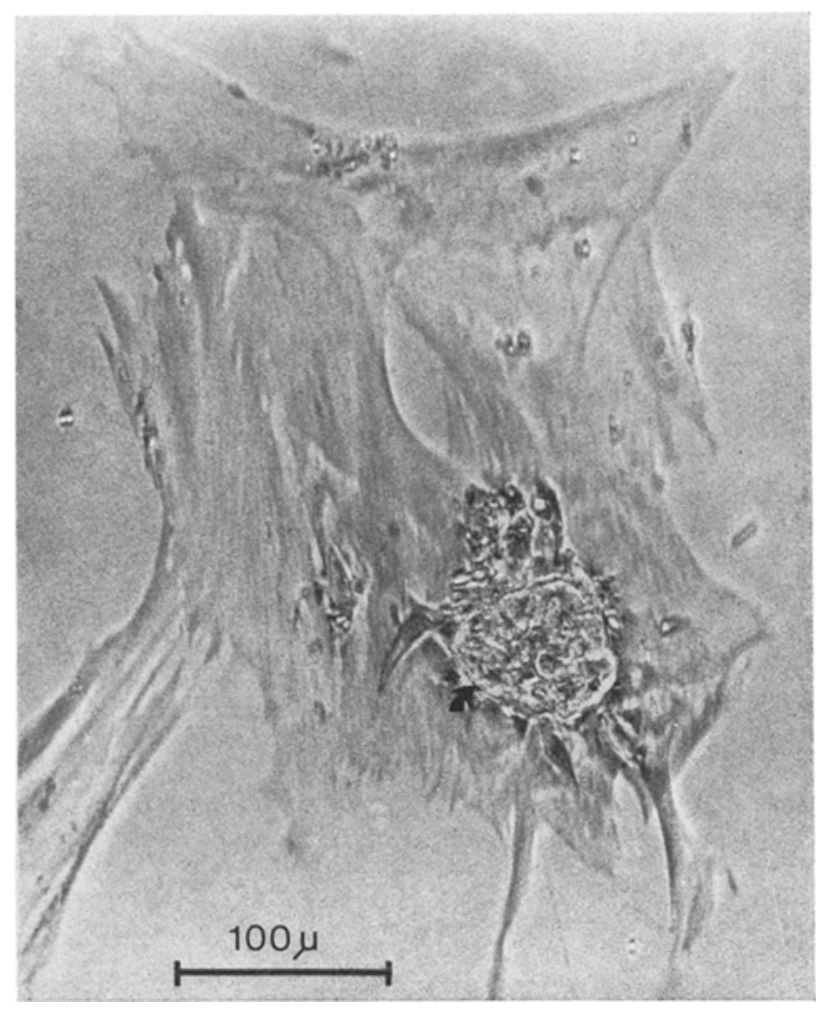

Fig. 1. Light microscopy (phase-contrast) of islet tumor cells after $3^{1} / 2$ months in culture. The arrow indicates a group of round cells, presumably $\beta$-cells, anchored to fibroblasts outgrowth. Tumor was from patient $S$ 


\section{Results and Discussion}

After 2 weeks in culture, populations of round cells, presumably $\beta$-cells, settled and anchored to outgrowths of fibroblasts (Fig. 1). During the course of our study the numbers of round cell colonies in the culture vessels seemed to increase. During the early period after the cells were put into culture, the aceumulation of IRI in the medium decreased rapidly, and stabilized after 25 to 30 days (Fig. 2a). The initially high level of IRI released may have been due to cell damage and cell death. After this initial period, the IRI in the medium appeared to represent the secretion of insulin by the surviving tumor cells. Fig. $2 \mathrm{~b}$ illustrates the timedependent process of hormone accumulation in the medium during a 5-day period.

Glucose and cyclic AMP stimulate insulin release from islets of pancreatic $\beta$-cells by mechanisms which
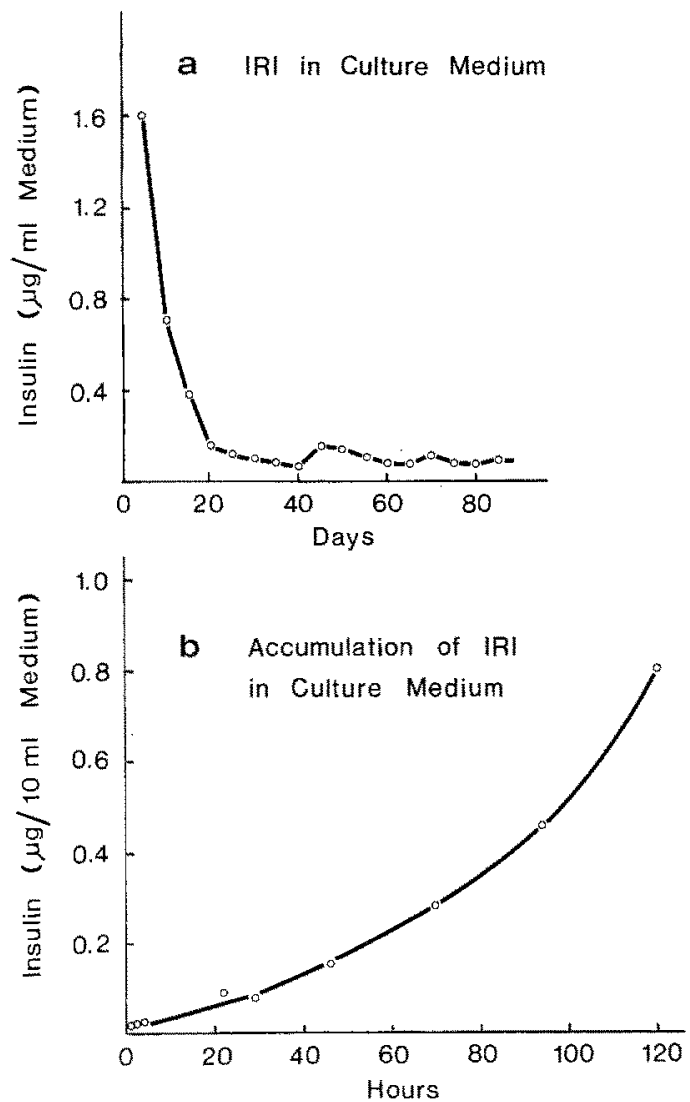

Fig. 2. Accumulation of IRI in culture medium with time. Tumor cells were from patient S. Immunoassay for insulin was carried out with guinea pig anti-insulin (bovine) serum. Bovine insulin served as standard. Each point is the average of duplicate analyses. a) Accumulation of IRI was monitored for 85 days. Aliquots of growth medium were taken for immunoassay at the time when the medium was changed. b) Accumulation of IRI was measured during a 5-day period. Aliquots of the medium were assayed for insulin at the times indicated. Tumor cells had been in culture for three months when this experiment was done. Each point is the average of duplicate analyses are not well understood. Glueagon and tolbutamide also stimulate insulin release, apparently by increasing the intracellular concentration of cyclic AMP [12]. Glucagon and tolbutamide can activate adenylate cyclase in homogenates of fresh human islet adenomas [13]. As shown in Table 1, the tumor cells in culture did respond to the addition of cyclic AMP or tolbutamide with increased release of insulin. Upon removal of the stimulant, the amount of insulin released returned to levels found prior to stimulation. A replicate culture of cells from the same patient maintained a stable rate of insulin release over the test period. Inasmuch as the tumor cells can respond to tolbutamide and cyclic AMP the adenylate cyclase system and the system responsive to cyclic AMP may be functionally intact.

Table 1. Stimulation of insulin release by cyclic AMP and tolbutamide

\begin{tabular}{llc}
\hline Day in culture & Treatment & $\begin{array}{l}\text { IRI } \\
\text { (ng/ml medium) }\end{array}$ \\
\hline 20 th & - & $40(25)$ \\
25 th & - & $45(15)$ \\
29 th & eyclic AMP $(1 \mathrm{mM})$ & $100(15)$ \\
34 th & - & $68(25)$ \\
40 th & - & $68(25)$ \\
46 th & - & $68(15)$ \\
51 st & - & $37(15)$ \\
55 th & tolbutamide $(1 \mathrm{mM})$ & $95(10)$ \\
$62 \mathrm{nd}$ & - & $45(10)$ \\
67 th & - & $40(10)$ \\
\hline
\end{tabular}

The experiment was carried out on tumor cells from patient $T$ after 15 days in culture. The compounds were added to the medium at the time of medium change, i.e., cyclic AMP on the 25th day and tolbutamide on the 51 st day, and were not removed until the next medium change. The values in brackets were from a parallel culture but without the addition of cyclic AMP or tolbutamide.

Glueagon $(10 \mu \mathrm{g} / \mathrm{ml})$ added to 2 -month old cultures of tumor cells did not cause an increase in IRI in the medium. The absence of glucagon sensitivity may reflect the inability of glucagon to activate adenylate cyclase within the cultured tumor cells. Similarly, high concentrations of glucose $(300 \mathrm{mg} \%)$ did not stimulate the release of insulin by cultured tumor cells when tested on the 15 th or 19 th day of culture. It is not known if the presence of contaminating fibroblasts might have contributed to this insensitivity. In contrast, glucose did stimulate insulin secretion in short-term monolayer cultures of neonatal rat pancreas [6].

When incubated with ${ }^{3} \mathrm{H}$-leucine, the tumor cells in culture incorporated the radioactive amino acid into both proinsulin and insulin, indicating that they were active in the biosynthesis of the hormone (Fig. 3). The low level of radioactivity incorporated was due to the nearly thousand-fold dilution of the specific radioactivity of ${ }^{3} \mathrm{H}$-leucine by nonradioactive leucine in the medium. DNA, RNA, and total protein synthesis were not measured in these cultures because of the limited 


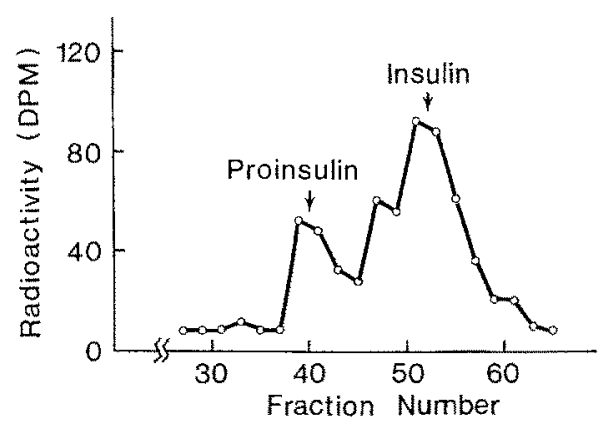

Fig. 3. Incorporation of ${ }^{3} \mathrm{H}-\mathrm{leucine}$ into proinsulin and insulin by islet tumor cells in culture. $30 \mathrm{uCi}$ of ${ }^{5} \mathrm{H}$-leucine (specifie radioactivity $40 \mathrm{Ci} / \mathrm{mmole}$ ) were added to a 36 day old culture. After $18 \mathrm{~h}$, the medium was removed and the cells were washed 3 times with fresh modium. The cells were resuspended in $5 \mathrm{ml}$ of medium and were precipitated with $5 \mathrm{ml}$ of $30 \%$ trichloroacetic acid (TCA). The precipitate, after washing with $10 \%$ TCA, was extracted with acid alcohol. The acid alcohol was evaporated to dryness, and the residue was dissolved in 3 $M$ acetic acid and chromatographed on a column of Biogel P.30 precalibrated with proinsulin and insulin as indicated by the arrows
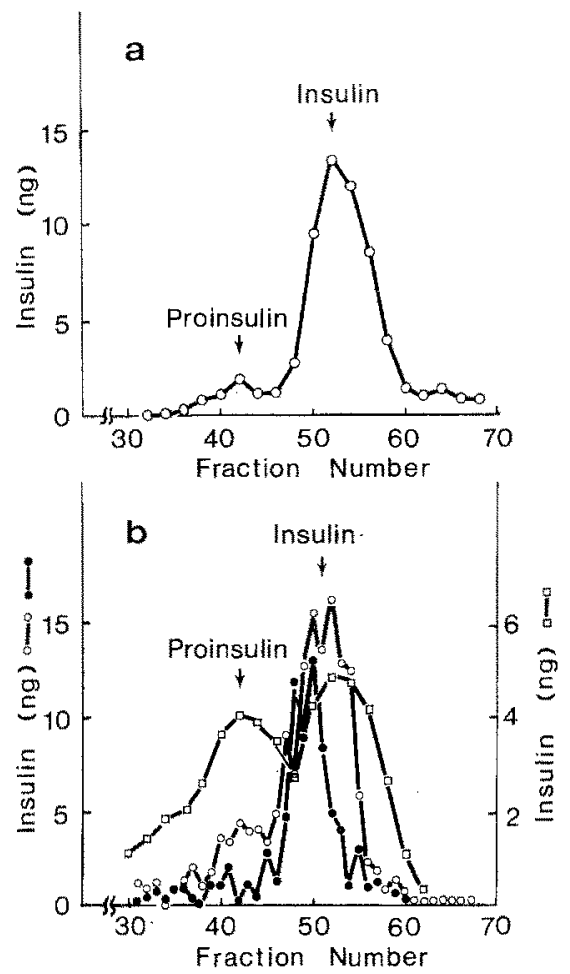

Fig. 4, a). Proinsulin and insulin in culture medium. Tumor cells were from patient $\mathrm{S} .2 \mathrm{ml}$ of the medium obtained at the time of medium change at 36 th day were extracted with alcohol and partially purified as described [14] before gel filtration on a column $(1.5 \mathrm{~cm} \times 90 \mathrm{~cm})$ of Biogel P. 30 in $3 \mathrm{M}$ acetic acid. The column was precalibrated with radioactive bovine proinsulin and insulin as indicated by the arrows. b) Proinsulin and insulin in extracts of normal pancreas (-), islet adenoma $(0-0)$, and pre-operative serum $(\square-\square)$ from fasting patient $T$. The normal pancreatic tissue and the adenoma were extracted by the method of Davoren [18]. Serum was extracted as described above for the culture medium. Gel filtration was performed as indicated above amount of $\beta$-cells obtained from the two tumors and because of the presence of contaminating fibroblasts. As illustrated in Fig. 4a, the IRI released by the cul. tured tumor cells from patient $\mathrm{S}$ consisted mostly of insulin with a small amount of proinsulin as identified by their elution volumes from gel-filtration and by their immunoreactivity to anti-insulin antibody. In contrast, the IRI in serum samples from fasting patients $T$ and $S$ before the removal of the tumor contained a large proportion of proinsulin (for example see Fig. 4b). High serum levels of proinsulin in patients with islet adenomas also have been observed by other investigators [14-16]. The ratio of proinsulin to insulin in an extract of the fresh tumor from patient $T$ was higher than that found in the extract of a normal piece of pancreas from the same patient, but much lower than that found in his serum (Fig. 4b).

These observations support the suggestions of Gorden el al. [16] that the high ratio of proinsulin to insulin in sera of patients with islet cell adenomas may be the result of a slower clearing rate of proinsulin from the circulation. It is not known if the insulin or proinsulin in these tumors was different from normal insulin or proinsulin. Arnold et al. [17] have recently reported immunohistological findings suggesting differences between insulin in normal human islets and insulin in human insulinomas.

In conclusion, we have shown that dissociated ha. man islet tumor cells can be kept in culture for long periods of time; that they can synthesize and release immunoreactive insulin; and that they are responsive to certain stimuli of insulin secretion.

Acknowledgements. This work was supported by the Medical Research Council of Canada. We thank Drs. N. Forbath and R. Ehrlich for the gift of the tumors.

\section{References}

1. Chen, J.M. : The cultivation in fluid medium of organized liver, pancreas and other tissues of foetal rats. Exp. Cell Res. 7, 518-529 (1954).

2. Schweisthal, M. R., Ceas, M.P., Wells, L.J.: Development of the pancreas of the rat embryo in vitro: islets and acini. Anat. Rec. 147, 149-155 (1963)

3. Murrell, L.R.: Mammalian pancreatic islet tissue in organ culture. T. Method of culture and in vitro histogenesis. Exp. Cell Res. 41, 350-364 (1966).

4. Moskalewski, S.: Isolation and culture of the islets of Langerhans of the guinea pig. Gen. comp. Endocr. 5, $342-353(1965)$.

5. Orei, L., Lambert, A.E., Kanazawa, Y., Amherdt, M., Rouiller, C., Renold, A.E.: Morphological and biochemical studies of $\beta$-cells of fetal rat endocrine pancreas in organ culture. Evidence for (pro)insulin biosynthesis. J. Cell Biol. 50, 565-582 (1971).

6. Lambert, A.E., Blondel, B., Kanazawa, Y., Orei, L., Renold, A.E. : Monolayer cell culture of neonatal rat pancreas: light microscopy and evidence for immuno. reactive insulin synthesis and release. Endocrinology 90, 239-248 (1972).

7. Murray, M.R., Bradley, C.F.: Two island cell adenomas of the human pancreas cultivated in vitro. Amer. J. Cancer 25, $98 \div 107$ (1935). 
8. Sando, H., Kemmler, W., Rubenstein, A.H., Steiner, D.F.: Studies on insulin biosynthesis and secretion in isolated islets and a cultivated beta-cell tumor. In: Insulin Action (Fritz, I.B., ed.) p. 77-114. New York, London: Academic Press 1972.

9. Eagle, H. : Amino acid metabolism in mammalian cell cultures. Science 130, 432-437 (1959).

10. Ham, R.G.: An improved nutrient solution for diploid Chinese hamsters and human cell lines. Exp. Cell Res. 29, 516-526 (1963).

11. Wright, P.H., Makulu, D.R., Vichick, D., Sussman, K.E.: Insulin immunoassay by back-titration; some characteristics of the technic and the insulin precipitant action of alcohol. Diabetes 20, 33-45 (1971).

12. Grodsky, G.M.: Insulin and the pancreas. Vitam. and Horm. 28, 37-101 (1970).

13. Levey, G. L., Schmidt, W.M. I., Mintz, D. H. : Activation of adenyl cyclase in a pancreatic islet cell adenoma by glucagon and tolbutamide. Metabolism 21, 93-98 (1972).

14. Melani, F., Ryan, W.G., Rubenstein, A.H., Steiner, D.F.: Proinsulin secretion by a pancreatic beta-cell adenoma. Proinsulin and C-peptide secretion. New Engl. J. Med. 283, 713-719 (1970).

15. Gutman, R.A., Lazarus, N.R., Penhos, J.C., Fajans, S., Recant, L.: Circulating proinsulin-like material in patients with functioning insulinomas. New Engl. J. Med. 284, 1003-1008 (1971).

16. Gorden, P., Sherman, B., Roth, J.: Proinsulin-like component of circulating insulin in the basal state and in patients and hamsters with islet cell tumors. J. clin. Invest. 50, 2113-2122 (1971).

17. Arnold, R., Douticke, U., Frerichs, H., Creutzfeldt, W.: Immunohistologic investigations of human insulinomas. Diabetologia 8, 250-259 (1972).

18. Davoren, P.R.: The isolation of insulin from a single cat pancreas. Biochim. biophys. Acta (Amst.) 63, $150-153(1962)$.

Prof. C.C. Yip; Prof, B.P. Schimmer

Banting and Best Department

of Medical Research

University of Toronto

Toronto 101, Ontario

Canada 